\title{
Farmer support for extending Conservation Compliance beyond soil erosion: Evidence from lowa
}

\author{
J.G. Arbuckle Jr.
}

\begin{abstract}
Conservation Compliance, which since its inception in 1985 has led to substantial reductions in soil erosion by linking eligibility for some Farm Bill programs to erosion control on highly erodible land, is at a critical juncture. Agricultural economic and budget factors have reduced the effectiveness of compliance incentives, and numerous groups are calling for enhancement of incentives and/or for extension of compliance beyond erosion control to cover concerns such as water quality impairment. This study analyzed survey data measuring Iowa farmers' support for four increasingly stringent Conservation Compliance scenarios ranging from the current configuration to a requirement that all farmers control nutrient runoff regardless of participation in Farm Bill programs. Overall, the results indicate that Iowa farmers have a generally positive view of Conservation Compliance policy, both as currently configured and in potentially more stringent and extensive forms. Farmers with stronger conservationist identities and attitudes were more likely to endorse increasing the scope and stringency of Conservation Compliance, while farmers who expressed greater levels of concern about the property rights implications of government intervention and those with more productivist orientations were less likely to support such policy changes. Taken as a whole, the results suggest that most Iowa farmers think that Conservation Compliance is a good idea should be continued, and should be extended to more farmers and other resource concerns.
\end{abstract}

Key words: attitudes—Conservation Compliance—-policy—water quality

\begin{abstract}
Conservation Compliance, which was introduced in the 1985 Farm Bill to tie eligibility to certain USDA programs to erosion control on highly erodible land (HEL) and which has led to substantial reductions in soil erosion, is at a critical juncture. The 2013 USDA budget proposes elimination of direct farm payments (USDA 2012), which have served as a primary motivation for farmer participation since the program's inception (Claassen 2012). At the same time, there have been mounting calls for mechanisms that increase the effectiveness of Conservation Compliance. In particular, proposed changes have centered on increasing the financial implications of noncompliance and extending compliance provisions to include water quality in addition to soil erosion (Perez 2007). The likely dissolution of a major component of the incentives for participation, combined with pressure to increase program scope and effectiveness, suggests
\end{abstract}

grasslands into crop production. Conservation Compliance has employed the Erodibility Index (EI), a measure that combines soil erosion potential and the rate at which a given soil can erode without degrading long-term productivity, to define which croplands are subject to compliance. Estimates indicate that 33 million ha (81 million ac) or $19 \%$ of US cropland have an EI of less than two, and are classified as nonerodible. An additional 88 million ha (218 million ac) or $52 \%$ of US cropland with an EI of greater than or equal to two and less than eight are classified as moderately erodible. Conservation Compliance applies to cropland with an EI equal to or greater than eight, which is classified as HEL (USDA ERS 1994), stipulating that farmers who crop HEL must take steps to address soil erosion in order to maintain eligibility for certain federal Farm Bill programs (Claassen et al. 2004).

Conservation Compliance is credited with major reductions in soil erosion. Between 1982 and 1997, for example, approximately $25 \%$ of reductions in annual cropland erosion, some 272 million $\mathrm{t}^{-1}$ (300 million tn $\left.\mathrm{yr}^{-1}\right)$, were directly attributable to Conservation Compliance (Claassen 2006). Claassen (2006) also notes that compliance provisions have led to sharp reductions in wetland conversion. Furthermore, nonmarket benefits to society accruing from Conservation Compliance have been estimated at US $\$ 1.4$ billion annually (Claassen et al. 2001).

Accomplishments notwithstanding, Conservation Compliance has come under consistent critique almost since its inception. In 1990, five years before the provision's deadline for implementation by farmers, the US Government Accounting Office (USGAO) assailed the program for falling short on erosion control. The USGAO estimated that while millions of hectares (acres) of cropland were covered under Conservation Compliance, some 114 million ha (281 million ac) of US cropland were still eroding at unsustainable rates (USGAO 1990). For example, USGAO (1990) estimated that 30 million ha (75 million ac) of cropland were eroding at rates between five and eight times the soil loss tolerance level $(\mathrm{T})$, the level below which soils may be allowed to erode without long-term damage to productivity, and mil-

J. Gordon Arbuckle Jr. is assistant professor of sociology and extension sociologist at lowa State University, Ames, lowa. 
lions more hectares of cultivated land had soil erosion potential above sustainable rates.

Further review by the USGAO and the USDA Office of the Inspector General focused on inconsistent and insufficient monitoring and enforcement of Conservation Compliance (USGAO 2003; USDA OIG 2002). A major target of these critiques was the "alternative conservation systems" option, enacted in 1988. This provision allowed farmers to implement alternative systems in situations in which it was not "economically feasible for farmers to reduce soil erosion to levels low enough to maintain the long-term productivity of the land" (USGAO 2003). This variance simply required farmers to "achieve 'significant' erosion reduction," but allowed cropping to continue on land with erosion potential well above T (Claassen et al. 2004).

Another critique of Conservation Compliance is that it does not include federally subsidized crop insurance among the benefits that can be denied. The degree to which the threat of withheld benefits can spur conservation behavior has come under serious scrutiny given the budgetary climate and crop economic situation of the early 2010s. Due to high grain prices, direct payments, which were once a central farm program benefit and a substantial component of net farm income, have declined in economic importance in recent years (White and Hoppe 2012). Such payments have also become difficult to justify in a time of sustained high crop prices and are slated for reduction or elimination (USDA 2012). It is critical to note that compliance programs depend a great deal on the relative economic importance of benefits that could be lost in the case of noncompliance, that is, the degree to which potentially withheld benefits exceed the cost of compliance. Since farm program benefits (i.e., conservation, commodity, and disaster payments) are set independently of compliance requirements, effective conservation leverage is not guaranteed (Claassen 2006). Federally subsidized crop insurance has come to represent a substantial proportion of farm program benefits (White and Hoppe 2012), but it is not part of the Conservation Compliance equation. If direct payments are eliminated, farmer incentives to retain conservation practices on HEL will be substantially reduced (Claassen 2012).

Other critiques have centered on Conservation Compliance's narrow focus on soil erosion. Water quality impairment from nutrient (and pesticide) runoff from agriculture has arguably eclipsed soil erosion as the top agri-environmental concern, yet is only addressed by Conservation Compliance indirectly (Perez 2007). Perez (2007) and Claassen et al. (2004) point out that the geographic areas with the highest levels of agricultural nutrient pollution are also largely those that receive the most farm program benefits. Both reports suggest that bringing nutrient management under the compliance umbrella could result in substantial reductions in water quality problems associated with agriculture.

In response to the above-mentioned critiques and nascent threats to the effectiveness of Conservation Compliance, numerous agricultural and environmental groups have called for both strengthening and expansion of the provisions (American Farmland Trust 2011; Cox et al. 2011; Izaak Walton League 2010; Perez 2007). A central argument behind these calls is that the policy principle underlying Conservation Compliance-that "taxpayer support for agriculture should not inadvertently subsidize degradation of natural resources or the environment"-is not being met (Perez 2007). Conservation Compliance does not apply to millions of hectares of land that are eroding at unsustainable rates (Cox et al. 2011), and nutrient runoff, which has become a major source of impairment of inland and coastal waterways (USEPA 2012), is not addressed sufficiently.

Farmer Perspectives on Conservation Compliance. Given the scope of Conservation Compliance, surprisingly little research has been directed at the farmers who must meet compliance stipulations. Compliance provisions cover 42 million ha (104 million ac), or 28\% of US cropland in production (USGAO 2003), dwarfing CRP's typical total of around 14 million ha (35 million ac) (Hellerstein 2006). While hundreds of studies over the past two decades have focused on voluntary conservation, including use of programs such as CRP and the Environmental Quality Improvement Program (see Prokopy et al. 2008 for a review of such studies), only a handful have centered on Conservation Compliance. Moreover, much of the research exploring farmer perspectives on Conservation Compliance was conducted in the late 1980s and early 1990s as the provisions took effect and farmers with HEL and other covered lands developed and implemented federally mandated conservation plans.
Some of that early research with farmers focused on the relationship between perceived risk associated with noncompliance and intentions to meet compliance (Esseks and Kraft 1991) and perceived effectiveness of various monitoring strategies (Esseks and Kraft 1993). Other studies examined intentions to comply and reasons for noncompliance (Esseks et al. 1997; Padgitt and Lasley 1993). All of the studies conducted at that time examined, to some degree, farmer attitudes toward Conservation Compliance. For the most part, research indicated that the provisions were acceptable to farmers and not viewed as overly onerous (Esseks and Kraft 1991; Napier and Napier 1991; Padgitt and Lasley 1993).

Nearly three decades after its inception, Conservation Compliance is once again in the spotlight. Pressure is mounting to increase its effectiveness by raising the financial stakes of noncompliance and extending it to encompass nutrient runoff. As discussions regarding the future of the program unfold, it is once again important to focus research on the group that would be most directly impacted by any changes in its provisions: farmers. This research seeks to understand farmer attitudes toward both current Conservation Compliance policy and potential changes in that policy. This article reports the results of a survey of Iowa farmers that elicited assessments of four potential Conservation Compliance scenarios that were developed based on current proposals for program reform. The four scenarios range from the current policy to a scenario that would require farmers to address nutrient runoff regardless of participation in federal farm programs.

\section{Materials and Methods}

Survey Data. Data from two waves of data (2009 and 2010) from the annual Iowa Farm and Rural Life Poll (IFRLP) were analyzed. The IFRLP is an annual panel survey of Iowa farmers that is conducted by mail by Iowa State University Extension in partnership with Iowa Agricultural Statistics and the Iowa Department of Agriculture and Land Stewardship. The 2009 survey was sent to 2,201 farmers and completed by 1,268 for a response rate of $58 \%$. The 2010 survey was sent to 2,224 farmers and completed by $61 \%$, or 1,360. The 2009 and 2010 samples were combined to bring several key variables into the analysis. The merging of the two data sets resulted in a two-year panel of 1,038 farmers. 
A brief note regarding the sample is warranted. To address attrition due to retirement and other factors, the survey panel is periodically refreshed with a random sample selected from the Census of Agriculture master list. As new samples are drawn to replenish the panel, smaller-scale farmers who do not consider themselves farmers, even though they are defined as such by the USDA because they could potentially produce US $\$ 1,000$ in sales, often choose not to participate. A comparison of IFRLP and Census of Agriculture statistics for Iowa shows that this process has led to a sample bias toward larger-scale farmers. IFRLP farmers operated an average of 180 ha (444 ac) in 2008, compared to 134 ha (331 ac) among the 2007 census population (table 1). A comparison of farm sales shows that $13.5 \%$ of IFRLP farmers had 2008 gross farm sales of less than US $\$ 10,000$, compared to $38.6 \%$ of the 2007 Census population. At the other end of the sales spectrum, $43.3 \%$ of IFRLP farmers had 2008 sales greater than US $\$ 100,000$, compared to $35.6 \%$ for the 2007 census population. While this bias toward larger-scale farmers might be seen as a liability for some research efforts, for this study it is considered an asset because larger-scale farms operate a disproportionate amount of acreage. For example, whereas only $16 \%$ of US farms generate US $\$ 100,000$ or more in gross sales, they operate $60 \%$ of farmland acreage (USDA NASS 2009). Thus, these larger Iowa farms would likely farm more land that is subject to Conservation Compliance, all other things being equal.

Variables in the Model. Four dependent variables are employed to help answer the study's central research questions: what do farmers think about Conservation Compliance as currently configured and what factors predict support for extension of the provisions to encompass nutrient runoff in addition to soil erosion? A preamble was provided that read as follows: "All Farm Bills enacted since 1985 have required that farmers with highly erodible land (HEL) be 'conservation compliant' by implementing USDA-approved soil conservation plans to remain eligible for most federal farm program benefits. We would like to know how you feel today about this 'Conservation Compliance' policy." Respondents were provided with the following statements (in quotes), in the order presented below, and asked to rate their agreement or disagreement on a scale from strongly disagree (1) to strongly agree (5):

\section{Table 1}

Comparison of farm characteristics: lowa Farm and Rural Life Poll (IFRLP) and Census of Agriculture for lowa (USDA NASS 2009).

\begin{tabular}{lcc}
\hline Characteristic & 2008 IFRLP & 2007 Agriculture Census (lowa) \\
\hline Average farm size (ha) & 180 & 134 \\
Farms with sales less than US\$9,999 (\%) & 13.5 & 38.6 \\
Farms with sales greater than US\$100,000 (\%) & 43.3 & 35.6
\end{tabular}

- Model 1: Erosion control for eligibility. "Farmers should be required to control soil erosion on highly erodible land to stay eligible for federal farm program benefits."

- Model 2: Erosion control regardless. "Farmers should be required to control soil erosion on highly erodible land regardless of participation in federal farm programs."

- Model 3: Nutrient runoff control for eligibility. "Farmers should be required to control nutrient runoff into ditches, streams, and other waterways to stay eligible for federal farm program benefits."

- Model 4: Nutrient runoff control regardless. "Farmers should be required to control nutrient runoff into ditches, streams, and other waterways regardless of participation in federal farm programs."

The first statement represents the status quo. To maintain eligibility for many USDA programs, farmers who crop HEL are currently required to follow conservation plans intended to reduce soil erosion. The second statement, while it still focuses on soil erosion, represents a substantial extension of the compliance concept because the provision that it proposes would require soil erosion control regardless of federal farm program participation. The third statement maintains the eligibility link to Farm Bill programs but extends Conservation Compliance beyond erosion control on HEL to control of nutrient runoff into proximate waterways. The final statement mirrors the second in that the scenario would require nutrient runoff control regardless of farm program participation. Taken together, the four statements represent scenarios of graduated stringency and scope.

Eight independent variables are employed in the analysis. Variables were selected based on previous research on farmers and Conservation Compliance, particularly Napier and Napier (1991) and Padgitt and Lasley (1993). Several additional variables were included based on review of literature focused on conservation behavior. Three of the variables are summated scales constructed from multiple items. Summated rating scales are viewed as better measures of attitudinal constructs than single-item scales or simple yes/no response categories because attitudes are complex and multidimensional (DeVellis 2003; McIver and Carmines 1981; Spector 1992). Summated scales that combine multiple single-item scales to measure attitudinal constructs can improve both reliability and precision of measurement.

Attitudes can be strong predictors of behaviors or acceptance of ideas (Ajzen 1991; Dietz et al. 2005). Positive attitudes toward the environment are increasingly understood to be necessary (though not sufficient) precursors to sustained conservation behavior (Heberlein 2012). Research on the role of attitudes in decisions to adopt agricultural conservation practices have found positive associations between awareness of environmental problems, attitudes toward potential solutions, and willingness to adopt those solutions (Prokopy et al. 2008). Strong positive attitudes toward pro-environmental behavior (Reimer et al. 2011) and the relative importance of production and stewardship values to farmer identities (Burton 2004; McGuire et al. 2012) have also been found to be important predictors of farmer conservation behavior. Research has shown that some farmers place more value on the outputs of agricultural production (e.g., yield and profit), while others tend to place more emphasis on conservation (Burton 2004). Of particular salience to this study is research reported in Davies and Hodge (2006), which found that strong stewardship orientations predicted support for extension of Cross Compliance (a British analog of Conservation Compliance) to encompass biodiversity concerns.

Two attitudinal scales measured farmer agricultural orientation. These scales were constructed from a set of survey items that were designed to assess what characteristics farmers believe are important to being a "good farmer." Building to an extent on Burton's (2004) explication of good farmer identities, respondents were provided with some 30 characteristics and asked to rate their importance in terms of defining what makes a good farmer. Factor analysis con- 
ducted on a larger set of items identified two constructs that are salient for this study: conservationism and productivism.

The first scale, labeled "conservationism," is comprised of eight items that were measured on a five-point scale ranging from not important at all (1) to very important (5). The items were as follows: a good farmer is one who

1. considers the health of streams that run through/along their land to be their responsibility,

2. minimizes soil erosion,

3. minimizes nutrient runoff into waterways,

4. maintains or increases soil organic matter,

5. manages for both profitability and minimization of environmental impact,

6. puts long-term conservation of farm resources before short-term profits,

7. scouts before spraying for pests/weeds/ disease, and

8. thinks beyond their own farm to the social and ecological health of their watershed.

Confirmatory factor analysis using principal components analysis with varimax rotation provided a Kaiser-Meyer-Olkin of 0.910, a Bartlett's test of sphericity of 0.000 , and factor scores between 0.696 and 0.859 . The items had a Cronbach's alpha reliability coefficient of 0.894 , indicating that the summated scale has a high level of internal consistency.

The second scale, labeled "productivism," is comprised of six items that were measured on the same five-point importance scale. The following items made up the scale: a good farmer is one who

1. has the highest yields per acre,

2. has the most up-to-date equipment,

3. uses the latest seed and chemical technology,

4. has the highest profit per acre,

5. gets their crops planted first, and

6. maximizes government payments.

Confirmatory factor analysis provided a $\mathrm{KMO}$ of 0.851 , a Bartlett's test of sphericity of 0.000 , and factor scores ranging from 0.628 to 0.780 . The items had a Cronbach's alpha reliability coefficient of 0.820 , indicating that this summated scale is also internally consistent. The expected relationship with endorsement of Conservation Compliance is positive for the conservationism scale and negative for the productivism scale.

A third attitudinal scale is a measure of concerns about privacy and property rights, specifically related to government conservation interventions. Napier and Napier (1991) found a strong negative relationship between beliefs that farmers should have autonomy to manage their land as they wish, without government interference, and favorable attitudes toward Conservation Compliance. Four survey items measured attitudes toward government conservation interventions on a five-point scale ranging from strongly disagree (1) to strongly agree (5). The items were as follows:

1. If a conservation professional contacted me about a potential natural resource concern on my land, I would allow them to come to assess it (reversed-coded for analysis).

2. Government use of satellite imagery and GIS to map characteristics of private land is an invasion of privacy.

3. In general, farmers contacted about resource concerns would feel unfairly singled out.

4. If a conservation professional contacted me about a potential natural resource concern on my land, I would feel unfairly singled out.

Confirmatory factor analysis was conducted and resulted in a KMO of 0.714, a Bartlett's test of sphericity of 0.000 , and factor scores of 0.696 to 0.856 . The Cronbach's alpha reliability coefficient for the items was 0.747 , indicating internal consistency for this summated scale.

Two additional conservation attitude items are included in the models. The first measures farmer perceptions regarding incidence of disproportionality. The principle of disproportionality holds that "inappropriate social behaviors within a particularly vulnerable setting can have a disproportionately large impact on overall environmental functioning of an ecological system" (Nowak et al. 2006). That is, behaviors that are inappropriate for a given place and/or time can produce impacts that are substantially higher than they would be at other places and times (Freudenburg 2005; Nowak et al. 2006; Nowak and Pierce 2007; Robertson et al. 2007). It has long been proposed that farmers who have the most serious natural resource concerns may be less likely to seek conservation assistance (Nielson 1986). Farm Poll participants were asked to rate, on a fivepoint agreement scale, their agreement or disagreement with the following statement: "Farmers who have more run-off and erosion problems are less likely to seek assistance with conservation.'"This item measures belief that (1) some farmers have a disproportionate impact on the environment, and (2) such farmers may be less likely to pursue conservation practices to ameliorate those impacts.

The second variable is a normative statement measuring farmers' attitudes toward potential action to ameliorate water quality problems. Napier and Napier (1991) found that awareness of agriculturally induced pollution was a positive predictor of favorable attitudes toward Conservation Compliance. The statement included in this study, "Iowa farmers should do more to reduce nutrient and sediment runoff into streams and lakes," can be viewed as a measure of both awareness of water quality problems associated with agriculture and attitudes toward actions to address the causes of those problems. This statement was also measured on a five-point agreement scale. It is expected that higher values on both of these variables will be associated with greater endorsement of Conservation Compliance.

Three variables measuring characteristics of the farm operation are employed. The first is a measure of whether farmers generally plant crops on HEL. This is a critically important variable, especially for the models that focus on erosion control. Farmers who crop HEL will for the most part have had experience with Conservation Compliance. While past research has found little difference in support for Conservation Compliance between farmers who did and did not crop HEL (Padgitt and Lasley 1993), that research focused on perceptions of the status quo. Any change in policies related to HEL, such as those offered in Model 2, would impact farmers who crop HEL specifically. In short, the extension of Conservation Compliance to HEL regardless of participation in farm programs implies regulation of their use of that land. It is expected that farmers who crop HEL will be less supportive of extensions of Conservation Compliance, particularly any changes relating to HEL.

A second measure of farm characteristics was perceived adequacy of conservation practices that farmers currently use. This variable is included in the models because it would be expected that farmers who are more confident in the degree to which the conservation practices they use are sufficient to address potential natural resource concerns would have more favorable attitudes toward potential increases in scope and stringency of Conservation Compliance. Farmers were provided with a list of nine conservation best management practices that are commonly 
used and promoted in Iowa: terraces; grassed waterways; conservation tillage; buffer strips of grass and/or trees along ditches, streams, and other waterways; contour buffer strips of grass or other perennial vegetation; manure management plan; nutrient management plan; cover crops; and integration of small grain or forage crops into crop rotations. For each of the practices listed, farmers were asked to indicate whether (1) they had established the practice to an adequate extent, (2) they should establish or improve the practice, (3) the practice was not needed or not applicable, or (4) they did not know. For this study, the first and third options were combined into a single measure of farmer perceptions that each practice was either adequately established or not necessary on the land they farm. The responses were summed into an overall measure of perceived adequacy of conservation practices employed, with higher values representing stronger farmer perceptions that they have their conservation bases adequately covered.

The final measure of farm characteristics is total acres of grain crops (corn, soybean, wheat, oats, sorghum, etc.) planted in 2009. Following Napier and Napier (1991), this variable is included as a control because the purpose of Conservation Compliance as currently configured is to reduce erosion on land cultivated for crops. In addition, grain crop farming is a major source of nutrient runoff; thus the two runoff scenarios would likely impact grain crop farmers more than farmers who do not produce grain. The sample contains a diverse mix of farms, most of which reported grain production in 2009. Some farms produced only grain crops (21\%), some had a mix of grain crops, other crops such as hay or vegetables, and livestock (43\%), others produced grain crops and other crops but no livestock (25\%), and some reported other crops only (2\%), livestock only (1\%), or CRP only $(3 \%)$. Five percent reported having neither crops nor livestock in 2009. Thus, about $90 \%$ of the farms in the sample produced at least some grain in 2009. Those farmers who did not produce grain in 2009 were assigned a value of zero for this variable.

Hypotheses. The expected relationships between the predictor variables and the dependent variables were generally outlined above. However, it is useful to state those relationships more explicitly in hypotheses to be tested through statistical modeling. The following hypotheses are proposed (variable name in parentheses):

- H1. Attitudes regarding agriculture and the environment

- H1a. Farmers with stronger conservation farmer identities (CONSERVATIONISM) will be more supportive of all Conservation Compliance scenarios.

- H1b. Farmers with stronger productivist identities (PRODUCTIVISM) will be less supportive of more stringent compliance scenarios.

- H1c. Farmers with greater concern about privacy and property rights (PROPRIGHTS) will be less supportive of all compliance scenarios.

- H1d. Farmers who believe that farmers with more natural resource issues are less likely to seek conservation assistance (DISPROP) will be more supportive of all compliance scenarios.

- H1e. Farmers who believe that more should be done to reduce agricultural runoff into water bodies (REDUCE) will be more supportive of all compliance scenarios.

- H2. Farm characteristics

- H2a. Farmers who believe that their land is adequately protected (PRACTICES) will be more supportive of (or at least indifferent to) all compliance scenarios.

- H2b. Farmers who generally crop HEL will be indifferent to the status quo but will not be supportive of making compliance more stringent, especially compliance that targets HEL.

- H2c. Farmers who have more acres in grain crops (GRAINACRES) will be indifferent to the status quo but will not be supportive of making compliance more stringent.

Analytical Approach. Multinomial logistic regression is employed to model the relationships between the dependent and independent variables. Multinomial logistic regression is an extension of logistic regression that is appropriate for analysis of noninterval outcome variables that have more than two categories (Tabachnik and Fidell 2007). The approach can be applied with either nominal or ordinal dependent variables, as one value (often the first or last in the case of ordered variables) is designated as the reference category, and the probability of being in the other categories is compared to the probability of being in the reference category (Menard 2002).

The dependent variables were transformed to facilitate analysis and interpretation of results. Because the outcome of interest is support for each given scenario, the three categories that represent nonagreement with each scenario, strongly disagree, disagree, and neutral, were combined into a single category. The resulting ordinal scale thus consists of "nonagree" (1), "agree" (2), and "strongly agree" (3). The nonagreement category was designated as the reference category, so the analysis calculates the probability of membership in the agree category compared to the nonagree category and the probability of being in the strongly agree category compared to the nonagree category, given the values of the independent variables.

\section{Results and Discussion}

Descriptive Statistics. Results for the dependent variables show substantial farmer support for all four compliance scenarios. For the item measuring support for the status quo, "farmers should be required to control soil erosion on highly erodible land to stay eligible for federal farm program benefits," $26.5 \%$ strongly agreed, $54.7 \%$ agreed, and $18.8 \%$ fell into the nonagree category (table 2). For the second item, which measures agreement with a scenario that would require erosion control on HEL regardless of farm program participation, $18.8 \%$ strongly agreed, 47\% agreed, and 34.2\% strongly disagreed, disagreed, or were neutral. Respondents also tended to agree with the statement, "Farmers should be required to control nutrient runoff into ditches, streams, and other waterways to stay eligible for federal farm program benefits," with $19 \%$ strongly agreed, $50.3 \%$ agreed, and the balance not in agreement. For the final scenario, which would require nutrient runoff control regardless of farm program participation, $15.3 \%$ strongly agreed, $47 \%$ agreed, and $37.7 \%$ were not in agreement.

Results for the three variables measuring attitudes toward conservation and environmental problems are presented in tables 3 and 4. Responses on the CONSERVATIONISM scale, which is constructed from eight fivepoint scale items, ranged from 16 to 40 and had a mean of 32.2. Percentage distributions, means, and standard deviations for each item are provided in table 3 . The mean for the variable measuring belief in disproportion- 
Table 2

Percentage distributions for dependent variables.

\begin{tabular}{|c|c|c|c|c|c|c|}
\hline $\begin{array}{l}\text { Variable } \\
\text { name }\end{array}$ & Item & $\begin{array}{l}\text { Strongly } \\
\text { disagree (\%) }\end{array}$ & Disagree (\%) & Neutral (\%) & Agree (\%) & $\begin{array}{l}\text { Strongly } \\
\text { agree (\%) }\end{array}$ \\
\hline $\begin{array}{l}\text { Erosion } \\
\text { control for } \\
\text { eligibility }\end{array}$ & $\begin{array}{l}\text { Farmers should be required to control soil } \\
\text { erosion on highly erodible land to stay } \\
\text { eligible for federal farm program benefits }\end{array}$ & 1.3 & 3.2 & 14.3 & 54.7 & 26.5 \\
\hline $\begin{array}{l}\text { Erosion } \\
\text { control } \\
\text { regardless }\end{array}$ & $\begin{array}{l}\text { Farmers should be required to control soil } \\
\text { erosion on highly erodible land regardless of } \\
\text { participation in federal farm programs }\end{array}$ & 2.7 & 9.6 & 21.9 & 47.0 & 18.8 \\
\hline $\begin{array}{l}\text { Nutrient runoff } \\
\text { control } \\
\text { regardless }\end{array}$ & $\begin{array}{l}\text { Farmers should be required to control nutrient } \\
\text { runoff into ditches, streams, and other waterways } \\
\text { regardless of participation in federal farm programs }\end{array}$ & 3.4 & 8.2 & 26.1 & 47.0 & 15.3 \\
\hline
\end{tabular}

ate environmental impacts (DISPROP) was 3.0 , with $29 \%$ agreeing with the statement, $30 \%$ disagreeing, and the balance uncertain. Most respondents (78\%) agreed that farmers should do more to address nutrient runoff (REDUCE), $18.5 \%$ were uncertain, and only $3.4 \%$ disagreed. The mean on this item was 3.88 .

The PRODUCTIVISM scale values ranged from 6 to 30, with a mean of 17.31 (table 3). Scores on the scale items indicate that the farmers in the sample placed less importance on these productivist elements of what it means to be a "good farmer" than they did on the conservation-oriented items in the CONSERVATIONISM scale. Nevertheless, substantial numbers of farmers place considerable importance on the role that high yields, use of the latest technology, and high profits play in defining their identity as farmers.

Results for the scale measuring concern about property rights (PROPRIGHTS) show that many farmers are not overly apprehensive about proactive conservation action by government conservation professionals (table 4). Nevertheless, responses indicate that many farmers do have concerns or are uncertain about the acceptability of such interventions. For example, 48\% were either uncertain or agreed that they would feel unfairly singled out if they were contacted about a potential resource concern on their land, and $62 \%$ were uncertain or agreed that government use of satellite and GIS technology to map characteristics of private land is an invasion of privacy. The scores on this scale ranged from 4 to 20 , and the mean was 10.63 .

Results for the three variables measuring characteristics of the farm operation are provided in table 5 . On average, farm- ers reported that 7.1 out a possible 9 key conservation practices (PRACTICES) had either been established to an adequate extent or were not necessary or applicable for the land they farm. It is important to recall that this variable measures the perceived adequacy of conservation practices from the farmer's perspective, not the objective effectiveness, need, or applicability. Forty percent of farmers reported that they generally crop HEL. Finally, land in grain production averaged 146 ha (360 ac).

Multinomial Logistic Regression Results. Regression results supported many of the hypotheses about relationships between the independent variables and the four Conservation Compliance scenarios. Model fit likelihood ratio tests produced significant $(p<0.001)$ chi-square statistics for models 1 through 4, indicating that all of the models adequately fit the data. The Nagelkerke pseudo $R$-square measure, a statistic that is employed in logistic regression as an analog to $r^{2}$ in multiple linear regression (Tabachnick and Fidell 2007), provided results of 0.289 , $0.226,0.284$, and 0.251 for models 1 through 4 , respectively, indicating that the models explain between $23 \%$ and $29 \%$ of the variance in the dependent variables.

Recall that multinomial logistic regression compares pairs of outcome categories. Each of the dependent variables has three outcome categories: not agree, agree, and strongly agree (for brevity's sake, these will be referred to as NA, A, and SA). The NA response is set as the baseline, or reference, category, so the results table is split into two sections. The top section presents statistics calculating the probability of membership in the A category compared to the NA category. The bottom section presents statistics calculating the probability of being in the SA category compared to the NA category. Results for all four models are reported in table 6.

Model 1: Erosion Control for Eligibility. The first model predicts agreement with the statement that describes Conservation Compliance as currently configured, with eligibility for farm program benefits tied to control of erosion on HEL. The results largely supported the hypotheses. CONSERVATIONISM is a strong positive predictor of both A and SA. The odds ratio $(\operatorname{Exp}[\mathrm{B}])$ is larger for the $\mathrm{SA}$ vs. NA comparison than for the A vs. NA comparison, indicating that increases in CONSERVATIONISM scores lead to increasing likelihood that respondents will agree or strongly agree with the statement rather than disagree or be neutral. Belief in disproportionality (DISPROP) and belief that farmers should do more to address water quality issues (REDUCE) are significant only for the SA vs. NA comparison; an increase in either variable increases the probability that the dependent variable response will be SA rather than NA. As expected, farmers who are more confident in the adequacy of their current conservation practices were more likely to select A or SA than NA.

Concern about government infringement on property rights through conservation interventions (PROPRIGHTS) is a strong negative predictor of support for Conservation Compliance, as hypothesized. Increases in the PROPRIGHTS scale scores translate into lower probabilities that respondents will select SA or A over NA. Three variables were not significantly associated with the dependent variable for either of the comparisons. Lack of significance for GRAINACRES and HEL is consistent with the hypothesis that 
Table 3

Means and percentage distributions: conservationism and productivism scales.

\begin{tabular}{|c|c|c|c|c|c|c|c|c|}
\hline $\begin{array}{l}\text { Variable } \\
\text { name }\end{array}$ & Item & Mean & SD & $\begin{array}{l}\text { Not important } \\
\text { at all (\%) }\end{array}$ & $\begin{array}{l}\text { Not really } \\
\text { important }(\%)\end{array}$ & $\begin{array}{l}\text { Somewhat } \\
\text { important (\%) }\end{array}$ & Important (\%) & $\begin{array}{l}\text { Very } \\
\text { important (\%) }\end{array}$ \\
\hline \multicolumn{9}{|c|}{ A good farmer is one who... } \\
\hline \multirow{2}{*}{\multicolumn{2}{|c|}{$\begin{array}{l}\text { CONSERVATIONISM } \\
\qquad \begin{array}{l}\text { 1. considers the health } \\
\text { of streams that run } \\
\text { through or along their } \\
\text { land to be their } \\
\text { responsibility }\end{array}\end{array}$}} & 32.20 & 4.410 & & & & & \\
\hline & & 4.05 & 0.729 & 0.4 & 1.5 & 17.4 & 54.3 & 26.4 \\
\hline & 2. minimizes soil erosion & 4.33 & 0.632 & 0.0 & 0.3 & 7.9 & 49.8 & 42.0 \\
\hline & $\begin{array}{l}\text { 3. minimizes nutrient } \\
\text { runoff into waterways }\end{array}$ & 4.33 & 0.647 & 0.0 & 0.5 & 8.3 & 48.8 & 42.4 \\
\hline & $\begin{array}{l}\text { 4. maintains or increases } \\
\text { soil organic matter }\end{array}$ & 4.20 & 0.651 & 0.0 & 0.4 & 12.0 & 55.0 & 32.5 \\
\hline & $\begin{array}{l}\text { 5. puts long-term } \\
\text { conservation of farm } \\
\text { resources before } \\
\text { short-term profits }\end{array}$ & 3.83 & 0.803 & 0.4 & 4.3 & 26.6 & 48.9 & 19.8 \\
\hline & $\begin{array}{l}\text { 6. scouts before spraying } \\
\text { for pests/weeds/disease }\end{array}$ & 3.90 & 0.761 & 0.7 & 2.7 & 22.1 & 54.8 & 19.7 \\
\hline & $\begin{array}{l}\text { 7. thinks beyond their own } \\
\text { farm to the social and } \\
\text { ecological health of } \\
\text { their watershed }\end{array}$ & 3.72 & 0.779 & 0.5 & 3.8 & 33.8 & 46.9 & 15.0 \\
\hline & $\begin{array}{l}\text { 8. manages for both profitability } \\
\text { and minimization of } \\
\text { environmental impact }\end{array}$ & 3.83 & 0.803 & 0.4 & 4.3 & 26.6 & 48.9 & 19.8 \\
\hline \multicolumn{2}{|c|}{ PRODUCTIVISM } & 17.31 & 3.940 & & & & & \\
\hline & $\begin{array}{l}\text { 1. has the highest yields } \\
\text { per acre }\end{array}$ & 3.11 & 0.851 & 3.1 & 18.7 & 45.3 & 29.7 & 3.3 \\
\hline & $\begin{array}{l}\text { 2. has the most up-to-date } \\
\text { equipment }\end{array}$ & 2.47 & 0.854 & 11.0 & 42.4 & 36.4 & 8.9 & 1.4 \\
\hline & $\begin{array}{l}\text { 3. uses the latest seed } \\
\text { and chemical technology }\end{array}$ & 3.25 & 0.898 & 3.0 & 16.2 & 39.9 & 35.1 & 5.9 \\
\hline & 4. has the highest profit per acre & 3.22 & 0.985 & 4.1 & 18.9 & 36.4 & 31.9 & 8.7 \\
\hline & 5. gets their crops planted first & 2.61 & 0.869 & 8.0 & 39.6 & 37.6 & 13.3 & 1.5 \\
\hline & $\begin{array}{l}\text { 6. maximizes government } \\
\text { payments }\end{array}$ & 2.67 & 0.968 & 11.0 & 33.5 & 36.0 & 16.9 & 2.6 \\
\hline
\end{tabular}

grain farmers and farmers who crop HEL would be indifferent regarding Conservation Compliance as currently configured because it would not entail changes for them. Results for PRODUCTIVISM, which was not significant, were not consistent with the hypothesis for this variable.

Model 2: Erosion Control Regardless. The second model assesses support for extension of the erosion control component of Conservation Compliance to all farmers, regardless of participation in farm programs. The CONSERVATIONISM scale is again significant and positive for both comparisons, with the odds ratios showing that increased commitment to stewardship as part of a "good farmer" identity leads to increasing likelihood that farmers will agree or strongly agree that compliance should be extended. Belief in disproportionality (DISPROP) is again significant only for the SA vs. NA comparison, but belief that farmers should do more to address water quality issues (REDUCE) is a significant and positive predictor for both comparisons.

Concern about the property rights implications of government interventions (PROPRIGHTS) is again negatively asso- ciated with support, and changes in the odds ratios indicate that the effects are stronger for the SA vs. NA comparison than for the A vs. NA comparison. As expected, the variable measuring whether farmers generally crop HEL becomes significant in this model, suggesting that such farmers would not support a change from the status quo. PRODUCTIVISM, PRACTICES, and GRAINACRES were not significant in this model.

Model 3: Nutrient Control for Eligibility. This model ascertains endorsement of a Conservation Compliance policy that 
Table 4

Means and percentage distributions for independent variables measured on a five-point agreement scale.

\begin{tabular}{|c|c|c|c|c|c|c|c|c|}
\hline Variable & Item & Mean & SD & $\begin{array}{l}\text { Strongly } \\
\text { disagree } \\
(\%)\end{array}$ & $\begin{array}{l}\text { Disagree } \\
\text { (\%) }\end{array}$ & $\begin{array}{l}\text { Uncertain } \\
\text { (\%) }\end{array}$ & $\begin{array}{l}\text { Agree } \\
(\%)\end{array}$ & $\begin{array}{l}\text { Strongly } \\
\text { agree (\%) }\end{array}$ \\
\hline \multirow[t]{5}{*}{ PROPRIGHTS } & & 10.63 & 2.480 & & & & & \\
\hline & $\begin{array}{l}\text { 1. If a conservation professional } \\
\text { contacted me about a } \\
\text { potential natural resource } \\
\text { concern on my land, I would } \\
\text { allow them to come to } \\
\text { assess it.* }\end{array}$ & 2.23 & 0.713 & 0.9 & 3.5 & 23.9 & 61.4 & 10.2 \\
\hline & $\begin{array}{l}\text { 2. If a conservation } \\
\text { professional contacted } \\
\text { me about a potential natural } \\
\text { resource concern on my land, } \\
\text { I would feel unfairly singled out. }\end{array}$ & 2.58 & 0.829 & 5.2 & 46.8 & 35.1 & 10.9 & 2.0 \\
\hline & $\begin{array}{l}\text { 3. In general, farmers contacted } \\
\text { about resource concerns would } \\
\text { feel unfairly singled out. }\end{array}$ & 2.89 & 0.785 & 1.7 & 29.9 & 47.8 & 18.8 & 1.8 \\
\hline & $\begin{array}{l}\text { 4. Government use of satellite } \\
\text { imagery and GIS to map } \\
\text { characteristics of private land } \\
\text { is an invasion of privacy. }\end{array}$ & 2.95 & 0.969 & 3.1 & 34.7 & 32.4 & 24.0 & 5.7 \\
\hline DISPROP & $\begin{array}{l}\text { Farmers who have more } \\
\text { runoff and erosion problems } \\
\text { are less likely to seek } \\
\text { assistance with conservation. }\end{array}$ & 3.00 & 0.841 & 1.5 & 28.3 & 41.2 & 26.6 & 2.4 \\
\hline REDUCE & $\begin{array}{l}\text { lowa farmers should do more } \\
\text { to reduce nutrient and sediment } \\
\text { runoff into streams and lakes. }\end{array}$ & 3.88 & 0.680 & 0.4 & 3.0 & 18.5 & 64.6 & 13.4 \\
\hline
\end{tabular}

* Reverse coded prior to analysis.

\section{Table 5}

Farm operation characteristics.

\begin{tabular}{|c|c|c|c|c|c|}
\hline Variable & Item & Mean & SD & Minimum & Maximum \\
\hline PRACTICES & Number of conservation practices adequate & 7.1 & 2.12 & 0 & 9 \\
\hline HEL & Proportion of farmers who generally crop highly erodible land & 0.4 & 0.49 & 0 & 1 \\
\hline GRAINACRES & Acres in grain production, 2009 & 360 & 513 & 0 & 5,800 \\
\hline
\end{tabular}

encompasses control of nutrient runoff as a condition for eligibility for farm program benefits. CONSERVATIONISM is a significant determinant of support for extension of Conservation Compliance to nutrient runoff control for both comparisons. DISPROP is once again significant only for the SA vs. NA comparison. As expected, belief that farmers should do more to reduce nutrient and sediment runoff into streams and lakes (REDUCE) is a highly significant predictor of support. The odds ratios for the A vs. NA and SA vs. NA comparisons indicate that increases in REDUCE are associated with higher likelihood that farmers would agree or strongly agree that Conservation Compliance should be extended to cover nutrient runoff.

PRODUCTIVISM is significant for the first time in this model. As hypothesized, it is a negative predictor of support for extending Conservation Compliance to nutrient runoff control but only for the SA vs. NA comparison. PROPRIGHTS was again a significant, negative predictor for both comparisons. PRACTICES, GRAINACRES, and HEL were not significant in this model.

Model 4: Nutrient Control Regardless. Model 4 is the most stringent of all proposed scenarios in that it would require that farmers control the movement of nutrients into waterways regardless of participation in federal farm programs. Patterns that emerged in the other models in large part continued. CONSERVATIONISM is a strong predictor of endorsement of this scenario as well. DISPROP is again associated with strong agreement with the statement of support for a more stringent compliance program. REDUCE is a positive predictor of both agreement and strong agreement.

PRODUCTIVSIM and PROPRIGHTS are negative predictors of support. Increases in scores for each of these variables significantly increase the odds that farmers will not agree that Conservation Compliance should be 
Table 6

Multinomial logistic regression results.

\begin{tabular}{|c|c|c|c|c|c|c|c|c|}
\hline & \multicolumn{2}{|l|}{$\begin{array}{l}\text { Model 1: } \\
\text { Erosion control } \\
\text { for eligibility }\end{array}$} & \multicolumn{2}{|l|}{$\begin{array}{l}\text { Model 2: } \\
\text { Erosion control } \\
\text { regardless }\end{array}$} & \multicolumn{2}{|l|}{$\begin{array}{l}\text { Model 3: } \\
\text { Nutrient control } \\
\text { for eligibility }\end{array}$} & \multicolumn{2}{|l|}{$\begin{array}{l}\text { Model 4: } \\
\text { Nutrient control } \\
\text { regardless }\end{array}$} \\
\hline & B (SE) & $\operatorname{Exp}(B)$ & B (SE) & $\operatorname{Exp}(B)$ & B (SE) & $\operatorname{Exp}(B)$ & B (SE) & $\operatorname{Exp}(B)$ \\
\hline \multicolumn{9}{|l|}{ Agree vs. not agree } \\
\hline Intercept & $-1.368(1.158)$ & & $-1.781(0.959)$ & & $-3.690 * * *(1.017)$ & - & $3.292 * * *(0.953)$ & \\
\hline CONSERVATIONISM & $0.102 * * *(0.026)$ & 1.108 & $0.060 * *(0.021)$ & 1.062 & $0.103 * * *(0.022)$ & 1.109 & $0.101 * * *(0.021)$ & 1.107 \\
\hline DISPROP & $0.165(0.119)$ & 1.179 & $0.127(0.096)$ & 1.136 & $0.049(0.100)$ & 1.050 & $0.163(0.094)$ & 1.177 \\
\hline REDUCE & $0.131(0.150)$ & 1.140 & $0.247 *(0.127)$ & 1.281 & $0.539 * * *(0.133)$ & 1.714 & $0.264 *(0.125)$ & 1.302 \\
\hline PRODUCTIVISM & $-0.020(0.027)$ & 0.980 & $0.002(0.022)$ & 1.002 & $-0.027(0.023)$ & 0.973 & $-0.016(0.021)$ & 0.984 \\
\hline PROPRIGHTS & $-0.184 * * *(0.042)$ & 0.832 & $-0.093 * *(0.035)$ & 0.911 & $-0.085^{*}(0.036)$ & 0.919 & $-0.056(0.034)$ & 0.946 \\
\hline PRACTICES & $0.126 * *(0.040)$ & 1.134 & $0.025(0.036)$ & 1.026 & $0.038(0.037)$ & 1.039 & $-0.014(0.035)$ & 0.986 \\
\hline GRAINACRES & $0.000(0.000)$ & 1.000 & $0.000(0.000)$ & 1.000 & $0.000(0.000)$ & 1.000 & $0.000(0.000)$ & 1.000 \\
\hline HEL (Yes = 0) & $-0.233(0.199)$ & 0.792 & $-0.483 * *(0.162)$ & 0.617 & $-0.123(0.168)$ & 0.884 & $-0.494 * *(0.159)$ & 0.610 \\
\hline \multicolumn{9}{|c|}{ Strongly agree vs. not agree } \\
\hline Intercept & $-10.252 * * *(1.528)$ & & $-10.731 * * *(1.490)$ & & $-12.789 * * *(1.588)$ & & $-12.703 * * *(1.689)$ & \\
\hline CONSERVATIONISM & $0.298 * * *(0.034)$ & 1.347 & $0.264 * * *(0.032)$ & 1.302 & $0.300 * * *(0.034)$ & 1.349 & $0.315 * * *(0.037)$ & 1.371 \\
\hline DISPROP & $0.333 *(0.142)$ & 1.395 & $0.356 * *(0.130)$ & 1.428 & $0.292 *(0.137)$ & 1.339 & $0.387 * *(0.142)$ & 1.473 \\
\hline REDUCE & $0.607 * *(0.199)$ & 1.836 & $0.628 * * *(0.193)$ & 1.875 & $1.057 * * *(0.211)$ & 2.877 & $0.730 * * *(0.217)$ & 2.076 \\
\hline PRODUCTIVISM & $-0.051(0.032)$ & 0.951 & $-0.046(0.028)$ & 0.955 & $-0.093 * *(0.031)$ & 0.911 & $-0.063 *(0.031)$ & 0.939 \\
\hline PROPRGHTS & $-0.234 * * *(0.052)$ & 0.792 & $-0.126 * *(0.049)$ & 0.882 & $-0.141 * *(0.052)$ & 0.869 & $-0.148 * *(0.055)$ & 0.862 \\
\hline PRACTICES & $0.153^{* *}(0.055)$ & 1.166 & $0.015(0.055)$ & 1.015 & $0.078(0.059)$ & 1.081 & $0.002(0.061)$ & 1.002 \\
\hline GRAINACRES & $0.000(0.000)$ & 1.000 & $0.000(0.000)$ & 1.000 & $0.000(0.000)$ & 1.000 & $0.000(0.000)$ & 1.000 \\
\hline HEL $(Y e s=0)$ & $-0.108(0.243)$ & 0.898 & $-0.528 *(0.228)$ & 0.590 & $-0.299(0.240)$ & 0.742 & $-0.654 * *(0.251)$ & 0.520 \\
\hline$n$ & 877 & & 877 & & 877 & & 875 & \\
\hline Nagelkerke $R^{2}$ & 0.289 & & 0.226 & & 0.284 & & 0.251 & \\
\hline Model $\chi^{2}$, df 16 & $250.65, p<0.001$ & & $192.56, p<0.001$ & & $248.40, p<0.001$ & & $213.95, p<0.001$ & \\
\hline
\end{tabular}

extended to nutrient runoff control regardless of farm program participation. The same is true for HEL. The results indicate that farmers who generally crop HEL were less likely to agree or strongly agree with the statement. PRACTICES and GRAINACRES were not significant in this model.

Discussion. The results of this research indicate that most Iowa farmers support Conservation Compliance. As expected, endorsement was highest for the provisions as currently configured: $81 \%$ of farmers either agreed or strongly agreed that control of erosion on HEL should be a prerequisite for farm program benefit eligibility. Only $4.5 \%$ of farmers disagreed. These results align well with previous research, albeit decades old, that found substantial levels of support for compliance provisions (Esseks and Kraft
1991; Napier and Napier 1991; Padgitt and Lasley 1993).

This study's novel contribution to the body of knowledge on farmer perceptions of Conservation Compliance lies in its examination of attitudes toward extension of the policy to cover more farmers and encompass water quality considerations in addition to soil erosion. Endorsement of the three scenarios that represent policies of graduated scope and stringency was substantial. Sixtysix percent agreed that farmers should be required to control erosion on HEL regardless of participation in federal farm programs (table 2). Sixty-nine percent agreed that Conservation Compliance should cover control of nutrient runoff. Sixty-two percent agreed that nutrient runoff control should be required regardless of program participation.
While agreement was lower for the scenarios that would extend coverage to all farmers, regardless of participation in Farm Bill programs, a solid majority endorsed all scenarios, and only small percentages ( $12 \%$ or less) disagreed with the statements.

A second important contribution of this research is identification of which farmer characteristics are associated with endorsement of varied compliance scenarios and which are related to lack of support. Proenvironmental identity and attitude were found to be strongly associated with endorsement of all compliance scenarios. Farmers who place more importance on the conservation dimensions of their identities as farmers were substantially more likely to approve of stronger Conservation Compliance policy. In addition, those who believe that farm- 
ers in general should do more to address water quality issues and those who believe more strongly that farmers with more serious agri-environmental problems are less apt to seek assistance with those problems were more likely to support extension of compliance policies beyond the status quo.

Equally important is an understanding of the characteristics associated with lower levels of support for changes in Conservation Compliance. Not surprisingly, farmers who believe more strongly that proactive conservation intervention by the government infringes on private property rights were less supportive of Conservation Compliance across the board. Indeed, they were significantly less likely to approve of compliance as currently configured, much less extending it to cover more farmers and additional resource concerns. That said, the proportion of farmers who expressed property rights concerns was small compared to those farmers who did not report such concerns. In sum, most Iowa farmers appear to support changes in Conservation Compliance policy that would lead to coverage of more farmers and encompass water quality concerns in addition to soil erosion.

These findings stand in sharp contrast to arguments against changes in Conservation Compliance. Major farm organizations, principal among them the Iowa Farm Bureau and Iowa Corn Growers Association, argue that changes such as linking Conservation Compliance to subsidized crop insurance or extending it to cover nutrients could lead to hardship for agricultural producers (AFBF 2012; Hill 2012; ICGA 2011). Results from this research indicate that Iowa farmers largely support maintaining or enhancing Conservation Compliance and thus do not appear to support such claims.

This study has several limitations that should be noted. One, it is not clear whether or not farmers were considering crop insurance when they responded to the two items that used the language "eligible for farm program benefits." Because crop insurance was not explicitly mentioned, some farmers may have been considering program benefits that have traditionally tied to compliance rather than crop insurance. That said, majorities of farmers endorsed policy scenarios that would require erosion control on HEL and nutrient runoff control on all land regardless of program participa- tion, which is much more stringent a policy than a link to crop insurance.

A second potential weakness stems from the lack of specification regarding the meaning of the phrase, "control nutrient runoff," and what steps such control might entail. Nutrient loss can be controlled to varying degrees through numerous agronomic and in-field and edge-of-field conservation practices. The items measuring support for linkage between nutrient runoff control and eligibility for farm program benefits did not specify the degree to which nutrient runoff would be controlled or what types of practices would be necessary to attain that control. It is possible some of the surveyed farmers may not have fully appreciated the implications of the statements. Nevertheless, we are confident that they understood that an extension of policy from erosion control to nutrient runoff control would be a shift in policy that would likely entail changes in behavior, at least for some farmers.

Another potential weakness stems from the limited geographic focus on Iowa farmers. These results may not be generalizable to farmers in other areas of the country. Iowa farmers do, however, participate in farm programs at relatively high rates (EWG 2012). Thus, their assessments of potential compliance scenarios may carry more weight than would responses from farmers in parts of the country where farm program benefits are less central to farming.

An important point to consider when evaluating the results of this research is the longstanding charge of lax monitoring and enforcement (USDA OIG 2002; USGAO 1990; USGAO 2003). If Conservation Compliance has not been implemented stringently, farmers may not have experienced much difficulty meeting their conservation plans and this could have influenced attitudes toward the potential changes that were posed. Farm Poll data from 2010 can provide some, but not conclusive, insight into this question. Sixty-one percent of Farm Poll respondents who plant crops on HEL reported that a USDA representative had visited their farm in the last 10 years to assess compliance. Of those farmers, only $2 \%$ reported that they had been found to be noncompliant, and just one-half of $1 \%$ reported that they had been denied benefits due to noncompliance. It is possible that lack of experience with the "teeth" of compliance could lead to inflated rates of endorsement. In such cases, positive attitudes toward an extended Conservation Compliance may not be rooted in experience and thus could be fragile and subject to change if policy shifts activate better-organized, competing attitudes (e.g., negative attitudes toward regulation; see Heberlein 2012 for discussion of relative strength of attitudes).

\section{Summary and Conclusions}

In summary, this research shows that Iowa farmers have a generally positive view of Conservation Compliance policy, both as currently configured and in potentially more stringent and extensive forms. That substantial majorities of farmers endorse proposals to extend its scope and effectiveness and small minorities oppose such an extension indicates that they consider Conservation Compliance to be an important component of conservation policy. Taken as a whole, the results suggest that farmers think that Conservation Compliance is a good idea, should be continued, and should be extended to more farmers and other concerns.

Another important finding is the strength of relationships between pro-conservation attitudes and support for more stringent Conservation Compliance mechanisms. Farmers who view conservation behavior as more central to their identities as farmers and those who believe that Iowa farmers in general should do more to address nutrient and sediment runoff were far more supportive of all scenarios. These results indicate that farmer conservation values are strongly correlated with support for pro-environmental policy and suggest that extension and outreach programs that focus on cultivating such values should be continued and enhanced.

In closing, it is clear that agricultural economic and budgetary factors have weakened Conservation Compliance substantially, and this trend will continue if direct payments are discontinued and compliance is not tied to other farm program benefits such as crop insurance subsidies (Claassen 2012). For critics who have long held that Conservation Compliance policy is not as effective as it could be (Cox et al. 2011; Perez 2007; Schnepf 2012), this trend is of deep concern. As noted above, many agricultural and environmental groups are calling for a strengthening of Conservation Compliance and other Farm Bill conservation programs (NSAC 2012). The results of this research suggest that efforts to improve the effectiveness of compliance policy would be largely supported by Iowa farmers. 


\section{References}

AFBF (American Farm Bureau Federation). 2012. Farm Bureau Policies for 2012. Honolulu, HI: American Farm Bureau Federation.

Ajzen, I. 1991. The theory of planned behavior. Organizational Behavior and Human Decision Processes 50(2):179-211.

American Farmland Trust. 2011. Conservation compliance: Safeguarding environmentally sensitive farm and ranch land. American Farmland Trust. http://www. farmbillfacts.org/wp-content/uploads/2011/11/ Conservation-Compliance.pdf.

Burton, R.J.F. 2004. Seeing through the 'good farmer's' eyes: Towards developing an understanding of the social symbolic value of productivist behavior. Sociologia Ruralis 44:195-215.

Claassen, R. 2006. Compliance provisions for soil and wetland Conservation. In Agricultural Resources and Environmental Indicators, eds. K. Wiebe and N. Gollehon, 184-193. Washington, DC: USDA Economic Research Service.

Claassen, R. 2012. The Future of Environmental Compliance Incentives in US Agriculture: The Role of Commodity, Conservation, and Crop Insurance Programs. Economic Information Bulletin No. 94. Washington, DC: USDA Economic Research Service.

Claassen, R., V. Breneman, S. Bucholtz, A. Cattaneo, R. Johansson, and M. Morehart. 2004. Environmental Compliance in US Agricultural Policy: Past Performance and Future Potential. Washington, DC: USDA Economic Research Service.

Claassen, R., L. Hansen, M. Peters,V. Breneman, M.Weinberg, A. Cattaneo, P. Feather, D. Gadsby, D. Hellerstein, J Hopkins, P. Johnston, M. Morehart, and M. Smith. 2001. Agri-Environmental Policy at the Crossroads: Guideposts in a Changing Landscape. Agricultural Economic Report No. 794. Washington, DC: USDA Economic Research Service.

Cox, C., A. Hug, and N. Bruzelius. 2011. Losing Ground. Ames, IA: Environmental Working Group.

Davies, B.B., and I.D. Hodge. 2006. Farmers' preferences for new environmental policy instruments: Determining the acceptability of cross compliance for biodiversity benefits. Journal of Agricultural Economics 57:393-414.

DeVellis, R.F. 2003. Scale Development: Theory and Applications. Thousand Oaks, CA: SAGE Publications.

Dietz, T., A. Fitzgerald, and R. Shwom. 2005. Environmental values. Annual Review of Environment and Resources 30(1):335-372.

Esseks, J.D., and S.E. Kraft. 1991. Land user attitudes toward implementation of conservation compliance farm plans. Journal of Soil and Water Conservation 46(5):365-370.

Esseks, J.D., and S.E. Kraft. 1993. Midwestern farmers' perceptions of monitoring for conservation compliance. Journal of Soil and Water Conservation 48(5):458-465.

Esseks, J.D., S.E. Kraft, and E.J. Furlong. 1997. Why targets of regulations do not comply: The case of conservation compliance in the Corn Belt. Journal of Soil and Water Conservation 52(4):259-264.

EWG (Environmental Working Group). 2012. Farm Getting Government Payments, By State, according to the 2007 USDA Census of Agriculture. Washington, DC: Environmental Working Group. http://farm.ewg. org/farms_by_state.php.

Freudenburg, W.R. 2005. Privileged access, privileged accounts: Toward a socially structured theory of resources and discourses. Social Forces 84:89-114.

Heberlein, T.A. 2012. Navigating Environmental Attitudes. New York: Oxford University Press.

Hellerstein, D. 2006. USDA land retirement programs. In Agricultural Resources and Environmental Indicators, eds. K. Wiebe and N. Gollehon, 175-183. Washington, DC: USDA Economic Research Service.

Hill, C. 2012. Farmers' concerns are not imaginary. Des Moines Register, 4 February 2012.

ICGA (Iowa Corn Growers Association). 2011. 2012 Policy of the Iowa Corn Growers Association. Johnston, IA Iowa Corn Growers Association.

Izaak Walton League of America. 2010. 2012 Farm Bill issue briefs: Conservation Compliance and crop insurance. In 2012 Farm Bill Issue Briefs: Conservation Compliance and Crop Insurance, Issue Brief. Gaithersburg, MD Izaak Walton League of America.

McGuire J., L. Morton, and A. Cast. 2012. Reconstructing the good farmer identity: Shifts in farmer identities and farm management practices to improve water quality. Agriculture and Human Values:1-13, doi: 10.1007/ s10460-012-9381-y.

McIver, J.P., and E.G. Carmines. 1981. Unidimensional Scaling. Thousand Oaks, CA: SAGE Publications Inc.

Menard, S. 2002. Applied Logistic Regression Analysis. Thousand Oaks, CA: SAGE Publications Inc.

Napier, T.L., and A.S. Napier. 1991. Perceptions of conservation compliance among farmers in a highly erodible area of Ohio. Journal of Soil and Water Conservation 46(3):220-224.

Nielson, J. 1986. Interorganizational relations in conservation training programs. In Conserving Soil: Insights from Socioeconomic Research, eds. S.B. Lovejoy and T.L. Napier, 40-51. Akeny, Iowa: Soil Conservation Society of America

Nowak, P., S. Bowen, and P.E. Cabot. 2006. Disproportionality as a framework for linking social and biophysical systems. Society \& Natural Resources 19:153-173.

Nowak, P., and FJ. Pierce. 2007. The disproportionality conundrum. In Managing Agricultural Landscapes for Environmental Quality: Strengthening the Science Base, eds. M. Schnepf and C.A. Cox, 104-111.Ankeny, IA: Soil and Water Conservation Society.

NSAC (National Sustainable Agriculture Coalition). 2012. Principles for Strengthening the Conservation Title. Washington, DC: National Sustainable Agriculture Coalition. http://sustainableagriculture.net/wp-content/ uploads/2011/09/Conservation-Title-Principles.pdf.
Padgitt, S., and P. Lasley. 1993. Implementing conservation compliance: Perspectives from Iowa farmers. Journal of Soil and Water Conservation 48:394-400.

Perez, M. 2007. Trouble Downstream: Upgrading Conservation Compliance. Washington, DC: Environmental Working Group.

Prokopy, L.S., K. Floress, D. Klotthor-Weinkauf, and A Baumgart-Getz. 2008. Determinants of agricultural best management practice adoption: Evidence from the literature. Journal of Soil and Water Conservation 63:300-311.

Reimer, A., A. Thompson, and L. Prokopy. 2012. The multidimensional nature of environmental attitudes among farmers in Indiana: Implications for conservation adoption. Agriculture and Human Values 29:29-40.

Robertson, G.P., L.W. Burger Jr., C.L. Kling, R. Lowrance, and D.J. Mulla. 2007. New approaches to environmental management research at landscape and watershed scales. In Managing Agricultural Landscapes for Environmental Quality, eds. M. Schnepf and C.A. Cox, 27-51.Ankeny, IA: Soil and Water Conservation Society.

Schnepf, M. 2012. Conservation compliance: A retrospective...and look ahead. Washington, DC: Environmental Working Group.

Spector, P.E. 1992. Summated Rating Scale Construction: An Introduction. Newberry Park, CA: SAGE Publications Inc.

Tabachnik, B.G., and L.S. Fidell. 2007. Using Multivariate Statistics. Boston: Pearson Education Inc.

USDA. 2012. Budget Summary and Annual Performance Plan. Washington, DC: USDA.

USDA ERS (USDA Economic Research Service). 1994 Agricultural Resources and Environmental Indicators, 1994. Washington, DC: United States Department of Agriculture. USDA NASS (National Agricultural Statistics Service). 2009 2007 Census of Agriculture. Washington, DC: USDA National Agricultural Statistics Service.

USDA OIG (USDA Office of the Inspector General) 2002 Natural Resources Conservation Service Compliance with Highly Erodible Land Provisions. Washington, DC: United States Department of Agriculture.

USEPA (US Environmental Protection Agency). 2012. National Summary of Impaired Waters and TMDL Information. U.S. Environmental Protection Agency. http://iaspub.epa. gov/waters10/attains_nation_cy.control?p_report_type $=\mathrm{T}$. USGAO (US Government Accounting Office). 1990. Conservation Compliance Provisions Could be Made More Effective. Washington, DC: US Government Accounting Office.

USGAO. 2003. Agricultural Conservation: USDA Needs to Better Ensure Protection of Highly Erodible Cropland and Wetlands. Washington, DC: US General Accounting Office.

White, T.K., and R.A. Hoppe. 2012. Changing farm structure and the distribution of farm payments and federal crop insurance. In Changing Farm Structure and the Distribution of Farm Payments and Federal Crop Insurance, Economic Information Bulletin. Washington, DC: USDA Economic Research Service. 